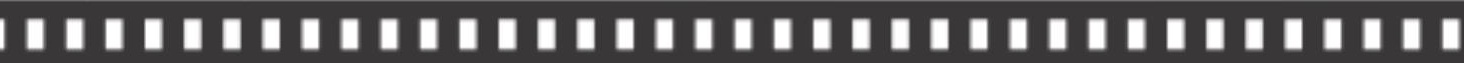 A UNE somos nós, nossa força e nossa voz... experiência fotográfica e os sentidos da história no século XX

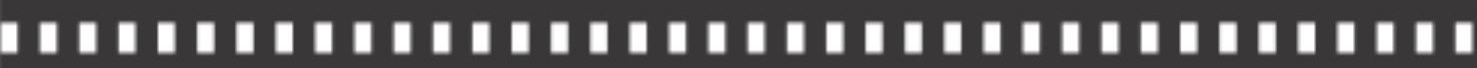

\author{
Ana Maria Mauad
}




\title{
A UNE somos nós, nossa força e nossa voz... experiência fotográfica e os sentidos da história no século $\mathrm{XX}^{*}$
}

\author{
UNE is us, our strength and our voice... \\ the photographic experience and meanings of history in $20^{\text {th }}$ century
}

\author{
Ana MariaMauad **
}

\begin{abstract}
Resumo: O artigo analisa a experiência fotográfica no século XX e enfatiza a relação entre autoria e engajamento político. Tem como objeto de estudo a cobertura fotográfica do XXXI Congresso da União Nacional de Estudantes (UNE), realizado em Salvador - Bahia, em 1979, pelo então fotojornalista Milton Guran. A análise incorpora as reflexões do filósofo italiano Giorgio Agamben (2007) para abordar a fotografia como gesto e o engajamento como autoria. Nesse sentido, parte da apresentação do material fotográfico das condições históricas de sua produção; em seguida apresenta as considerações do filósofo sobre a criação no mundo capitalista; finalmente relaciona as entrevistas realizadas com o fotógrafo Milton Guran sobre o trabalho no Congresso da UNE e a sua percepção a respeito do ato fotográfico, a uma imagem síntese do processo de criação.
\end{abstract}

Palavras-chave: Fotografia; autoria; movimento estudantil; política; engajamento.

\begin{abstract}
This article analyses the $20^{\text {th }}$ Century photographic experience and emphasizes the relation between authorship and political engagement. The object of this study is the photographic coverage of the UNE Meeting, in Salvador, BA, 1979, made by the Milton Guran. The analysis embodies the Italian philosopher Giorgio Agamben' reflections in order to understand photographic as a gesture and engagement as authorship. In this sense, this article starts by presenting the historical conditions photography of his production; secondly, it discusses the philosopher' considerations about authorship under a capitalist society; finally it relates Milton Guran' interviews about his work at UNE's Congress and his perception about the photographic act with a unique photograph that synthesis his creation process.
\end{abstract}

Key-words: Photography; authorship; student movement; politics; political engagement.

\footnotetext{
* Esse artigo integra o projeto de pesquisa Imagens Contemporâneas: prática fotográfica e os sentidos da história na imprensa ilustrada (Brasil, 1940-1970), financiado pelo CNPq com bolsa de produtividade e IC. Participaram da pesquisa os bolsistas IC: Clarissa Minardi e Luciano Gomes. ** Doutora em História pela Universidade Federal Fluminense - UFF. Professora Associada da UFF. Pesquisadora do CNPq. Coordenadora do LABHOI-UFF.
} 


\section{Introdução}

A experiência fotográfica no século XX definiu um novo regime visual que democratizou o retrato e pluralizou as formas de representação do sujeito na esfera pública e privada. Dos recônditos da intimidade às praças públicas, a fotografia enquadrou memórias, registrou acontecimentos, capturou imagens de significativa beleza, flagrou personalidades, encampou as lutas sociais, dimensionando a história contemporânea em seus múltiplos sentidos. Não se busca mais apenas a história por detrás das imagens, mas a história das imagens e dos sujeitos que, atentos às transformações do mundo, produziram essas mesmas imagens. A forma como foram elaboradas e o envolvimento dessa prática fotográfica com os acontecimentos e vivências que registrava definem um lugar social para o fotógrafo ou fotógrafa que as produziu e, ao mesmo tempo, aponta para o pertencimento desses com seu grupo ou sua geração ${ }^{1}$.

A fotografia pública, ao longo do século passado, pode ser compreendida segundo dois rumos: o da prática criativa e da expressão crítica do mundo visível. (KRACAUER, 1980). No primeiro caminho, o da prática criativa, a fotografia, entre várias tendências, foi pensada por um lado como expressão autoral ligada ao pictorialismo e aos padrões clássicos de representação artística; de outro, associada às vanguardas artísticas, colocou em questão o próprio princípio realista. No segundo caminho, esteve associada à imprensa ilustrada e à produção das notícias, agindo como janelas que se abriam para o mundo, figurando-o da forma mais realista, e foram consideradas "o olho da história", na feliz expressão do fotógrafo da Guerra Civil Americana, Mathew Brady.

Ainda nesse segundo rumo ou tendência, a produção fotográfica novecentista associou-se às práticas de registro social, servindo para

\footnotetext{
${ }^{1}$ Operamos o conceito de geração como uma escala temporal, variável, definida a partir do conjunto de experiências sociais que constroem o universo da cultura política de uma época. Sobre esse conceito ver: SIRINELLI, Jean-François. A geração. In: FERREIRA, Marieta; AMADO, Janaína (Org.). Usos e abusos da história oral. Rio de Janeiro: Fundação Getúlio Vargas, 1996. p.131-138.
} 
documentar as condições de vida de diferentes setores sociais, os deslocamentos humanos, conflitos e situações-limite. Nesse caso, o agenciamento das imagens poderia ser feito de forma independente, como os exemplos das agências fotográficas independentes Dephot e Magnum, ou associada a projetos governamentais como no caso da Farm Security Administration, agência governamental, criada nos anos 30, entre outras funções, para documentar a recuperação dos Estados Unidos, durante a recessão. Entretanto, tanto em um como em outro tipo de agenciamento a autoria fotográfica se define pelo engajamento em uma causa ou projeto. (MAUAD, 2008).

Esse texto aborda uma das experiências da fotografia pública ligada ao engajamento a uma causa, assim se debruça sobre a cobertura fotográfica do Encontro da UNE, em 1979, em Salvador(BA), realizada, de forma independente, pelo então fotojornalista Milton Guran². Esta iniciativa se inscreve no contexto de surgimento de uma nova atitude em relação à prática fotográfica por uma geração de fotógrafos e fotógrafas responsáveis pelo movimento das agências independentes ${ }^{3}$. Uma geração formada por jovens entre 20 e 30 anos que chamou para si o direito e o dever de ser testemunhas oculares (da história) do seu tempo. Assim, munidos de câmeras, rolos de filmes Tri-X rebobinados, engajaram-se nas lutas sociais e num gesto autoral enquadraram a memória produzindo uma história em imagens. Vale registrar que essa reflexão se insere em uma mais ampla, a que discute os sentidos da história e a experiência fotográfica contemporânea ${ }^{4}$.

Há algum tempo venho trabalhando com a trajetória de fotógrafos e fotógrafas, principalmente, mas não exclusivamente, fotojornalistas. Meu propósito nesse estudo é o de analisar as diferentes práticas fotográficas,

\footnotetext{
${ }^{2}$ Milton Guran, doutor em Antropologia pela Ecoles des Hautes Etudes en Sciences Sociales, França, pesquisador associado do LABHOI-UFF e coordenador geral do FotoRio.

${ }^{3}$ Sobre o papel das agências nesse período da história do Brasil ver: Ciclo de Palestras sobre fotografia, 1. Rio de Janeiro, 27 outubro/29 dezembro, 1982. Especialmente os depoimentos de Nair Benedicto, Assis Hoffmann, Milton Guran e Zeka Araújo. Confira também: MAGALHÃES, Ângela; PEREGRINO, Nadja Fonseca. A fotografia no Brasil: um olhar das origens ao contemporâneo. Rio de Janeiro: Funarte, 2004.

${ }^{4}$ Associada à linha de pesquisa do LABHOI-UFF, Memória e Mídias.
} 
no mundo contemporâneo, como experiência de ver e conhecer. Os sentidos que orientam o ato fotográfico são múltiplos e a fotografia é sempre uma síntese da pluralidade desse mundo sensível. O tempo desse ato, no mundo contemporâneo, é o instante que na famosa expressão de CartierBresson, "é decisivo", por isso evoca a presença de um sujeito atento que pensa, vê e captura. Daí o meu interesse pelos donos desse olho que pensa segundo as considerações de Kracauer (1980) e do autor como gesto, como propõe Agamben (2007). Das trajetórias que venho recompondo, a do fotógrafo e antropólogo Milton Guran é significativa para compreender os múltiplos usos de funções da fotografia como experiência social.

Na composição do trabalho utilizo a metodologia da história oral, com a realização de entrevistas temáticas acompanhadas das imagens produzidas na cobertura do encontro da UNE de 1979, publicadas em livro poucos meses após o evento, como uma estratégia de torná-lo um acontecimento público (GURAN, 1979). Seu trabalho como freelancer no final dos anos 70 serve, assim, de pretexto (ou ainda pré-texto) para refletir a fotografia como gesto e o engajamento como autoria, e para tanto apresento um caminho teórico.

\section{O autor como gesto, a propósito das reflexões de Giorgio Agamben}

Giorgio Agamben, filósofo italiano, seguidor de Walter Benjamin e leitor atento de Michel Foucault, é um dos importantes nomes da renovação do pensamento de esquerda na atualidade ${ }^{5}$. Olgária Matos, na orelha do livro de Agamben, intitulado Profanações, apresenta o sentido do título e a proposta de reflexão do filósofo:

\footnotetext{
${ }^{5}$ Sua obra no Brasil vem sendo publicada pela editora paulista Boitempo, identificada pelos autores e títulos que publica, com a renovação do pensamento marxista na atualidade.
} 
[...] refere-se aos interstícios da cultura capitalista, na qual se expressa a ultrapassagem da economia de mercado pela sociedade de mercado, pela universalização do fenômeno do fetichismo em sua estrutura desrealizante. [...] Estado de separação e perda radical, o capitalismo profana a transcendência teológica e instaura o culto à mercadoria [...] bloqueia a percepção dos mecanismos religiosos do capitalismo, garantido, nisso, pela ausência de critérios de verdade no mundo moderno, de certezas metafísicas e razão objetiva.[....] Profanações indicia a teodicéia capitalista, para fazer justiça ao rastro do trabalho humano esquecido na mercadoria e que é preciso, em definitivo, profanar. Reapropriandose dos produtos objetivados de sua subjetividade, o homem toma posse de si, usando-os. (MATOS, 2007- orelha).

Leio em Agamben, orientada por essas breves ponderações de Matos, as possibilidades de dimensionar a presença do sujeito na sua produção visual e assim "desalienar", "desfetichizar", humanizar as imagens. Do livro, Profanações, composto por dez ensaios que abordam gênios, ajudantes, limbos, paródias, desejos e felicidade, aproprio-me da reflexão de dois deles: O autor como gesto (p.55-64) e o Dia do Juízo (p.27-30), para propor um caminho para pensar a fotografia como gesto.

No primeiro ensaio, Agamben (2007) busca a presença do sujeito no texto pela marca da tangibilidade do gesto que produz o próprio texto. A situação de uma presença ausente redefine a concepção de autoria. $\mathrm{O}$ filósofo italiano toma como referência a discussão proposta por Foucault quando da apresentação em 1969 da conferência "O que é um autor?"

Nessa ocasião, Foucault (1992, p.132) parte de uma referência a Beckett: "O que importa quem fala, alguém disse, o que importa quem fala", para afirmar a indiferença do autor como mote ou princípio fundamental da ética da escritura contemporânea. Para Foucault (1992, p.132) "a marca do autor está unicamente na singularidade da sua ausência". No entanto, para Agamben (2007, p.55), "a citação de Beckett apresenta no seu enunciado uma contradição", pois alguém que, mesmo anônimo e sem rosto, proferiu o enunciado, alguém sem o qual a tese - que nega a 
importância de quem fala - não poderia ter sido formulada. "O mesmo gesto que nega qualquer relevância à identidade do autor, afirma, no entanto, a sua irredutível necessidade."

Na continuação de sua apresentação da tese, Foucault anota a diferenciação que faz entre um autor como indivíduo real, rigorosamente fora de campo, e a função-autor, a única na qual Foucault concentrará toda a sua análise. O nome do autor não é simplesmente um nome próprio como os outros, nem no plano da descrição nem naquele da designação. Ainda segundo Foucault, afirma Agamben (2007, p.56): "Poder-se-ia afirmar, portanto, que em uma cultura como a nossa, há discursos dotados da função-autor, e outros que são desprovidos dela [...] a função-autor caracteriza o modo de existência, de circulação e de funcionamento de certos discursos no interior de uma sociedade."

O problema da subjetividade em Foucault revela-se um caminho interessante para Agamben explorar a problemática do sujeito no capitalismo avançado. Assim, as acusações a Foucault de dissolver o sujeito nas entranhas de uma "episteme a-histórica" é rebatida pelo autor italiano:

Nessa divisão entre o sujeito-autor e os dispositivos que consolidam a sua função na sociedade, volta a aparecer um gesto que marca profundamente a estratégia foucaultiana. Por um lado, ele repete com alguma freqüência que nunca deixou de trabalhar sobre o sujeito; por outro, no contexto das suas pesquisas, o sujeito como indivíduo vivo sempre está presente apenas através dos processos objetivos de subjetivação que o constituem e dos dispositivos que os inscrevem e capturam nos mecanismos de poder. [...] Aliás, Foucault tinha plena consciência dessa aparente aporia. Ao apresentar, no início dos anos 80 , o próprio método para o Dictionnaire des philosophes, ele escrevia que "rejeitar o recurso filosófico a um sujeito constituinte não significa agir como se o sujeito não existisse, e fazer disso, uma abstração a favor da pura subjetividade; tal rejeição tem, sim, por objetivo fazer aparecer os processos próprios que definem uma experiência na qual o sujeito e o objeto se 'formam e se transformam' um em relação ao outro e em função do outro". E a Lucien Goldmann que, no debate 
após a conferência sobre o autor, lhe atribuía a intenção de cancelar o sujeito individual, ele podia responder ironicamente: 'definir como se exerce a função-autor ...não equivale dizer que o autor não existe $[. .$.$] retenhamos portanto as lágrimas'. (AGAMBEN,$ 2007, p.57).

Segundo Agamben (2007, p.58), Foucault reafirma que "a marca do escritor reside justamente na singularidade da sua ausência; a ele cada papel morto no jogo da escritura". Assim, continua Agamben (2007, p.58), “o autor não está morto, mas pôr-se como autor significa ocupar o lugar do morto. [...] E o que significa, para um indivíduo, ocupar o lugar do morto, deixar as próprias marcas em um lugar vazio?"Nesse momento, o autor procura as marcas dos sujeitos nos lugares vazios que o próprio Foucault deixa nas suas obras, dentre elas a que dedica mais atenção é $A$ vida dos homens infames, de 1982, uma recopilação de documentos do século XVIII, antecedida de uma introdução tomada com muita atenção pelo filósofo italiano.

A vida de homens comuns, acusados pela justiça e jogados na história pelos dispositivos da sua sujeição, é definida pela sua existência no texto. Ali, eles existem como uma presença ausente da mesma forma que o autor do documento. Agamben questiona onde estão os personagens, as pessoas citadas na vida dos infames? E responde que não estão nas observações lacônicas dos arquivos, nem numa possível existência biográfica da qual nada sabemos. Assim, onde estaria o sujeito no texto?

Eles estão no umbral do texto em que foram postos em jogo ou quem sabe, a sua ausência, o seu voltar às costas para nós para sempre se põem nas bordas do arquivo, como o gesto que ao mesmo tempo, o tornou possível e lhe excede e anula a intenção... Ela é apenas jogada, nunca possuída, nunca representada, nunca dita - por isso ela é o lugar possível, mas vazio, de uma ética, de uma forma-de-vida. (AGAMBEN, 2007, p.60).

A noção de pôr em jogo implica na reflexão do filósofo na incorporação de uma experiência vivencial que não pode ser descrita, 
mas concebida nas suas marcas gestuais. Nesse momento do texto, Agamben (2007, p.61-62) define o lugar do autor e gesto que o define como sujeito:

O autor marca o ponto em que uma vida foi jogada na obra. Jogada, não expressa; jogada, não realizada. Por isso, o autor nada pode fazer além de continuar, na obra, não realizado e não dito. Ele é o ilegível que torna possível a leitura, o vazio lendário de que procedem a escritura e o discurso. O gesto do autor é atestado na obra a que também dá vida, como uma presença incongruente e estranha [...]. No entanto, precisamente o gesto ilegível, o lugar que ficou vazio é o que torna possível a leitura [...]. O lugar - ou melhor, o ter lugar - do poema não está, pois, nem no texto nem no autor (ou no leitor): está no gesto no qual o autor e leitor se põem em jogo no texto e, ao mesmo tempo, infinitamente fogem disso. $\mathrm{O}$ autor não é mais que a testemunha, o fiador da própria falta na obra em que foi jogado; e o leitor não pode deixar de soletrar o testemunho, não pode por sua vez, deixar de transformar-se em fiador do próprio inexausto ato de jogar de não se ser suficiente [...]. No entanto, o texto não tem outra luz a não ser aquela - opaca - que irradia do testemunho dessa ausência. Precisamente por isso, porém, o autor estabelece também o limite para além do qual nenhuma interpretação pode ir. Onde a leitura do poetado encontra, de qualquer modo, o lugar vazio do vivido, ela deve parar. Pois tão ilegítima quanto a tentativa de construir a personalidade do autor através da obra é a de tornar seu gesto a chave secreta da leitura.

Dessa maneira, conclui o autor, o sujeito/autor não é algo que possa ser alcançado diretamente de uma realidade substancial presente em algum lugar. Ele é o que resulta da experiência com os dispositivos (aqui no sentido de Foucault, ou seja, práticas e estratégias de sujeição) em que foi posto - se pôs - em jogo. Para Agamben (2007, p.62), este é um dado importante a considerar:

A escritura - toda a escritura, e não só a dos chanceleres do arquivo da infâmia - é um dispositivo, e a história dos homens talvez não seja nada mais do que um incessante corpo-a-corpo com os dispositivos que eles mesmos produziram - antes de 
qualquer outro, a linguagem [...]. Uma subjetividade produz-se onde o ser vivo, ao encontrar a linguagem e pondo-se nela em jogo sem reservas, exibe em um gesto a própria irredutibilidade a ela.

O segundo ensaio que, na ordenação o livro vem antes desse acima apresentado, aborda a fotografia como gesto para impedir o esquecimento. A marca de presença do sujeito na imagem pelo gesto de captura que realiza o fotógrafo transforma qualquer experiência banal num momento excepcional, no qual somos enfrentados com o dia do Juízo Final. Toda a explicação para todas as coisas foram potencializadas naquela marca de presença inscrita numa superfície fotográfica como um devir. É a marca de uma presença ausente, dela só existe a sombra da impregnação luminosa possibilitada pelo gesto do fotógrafo - ou ainda o 'isto foi' de Roland Barthes. (BARTHES, 1974).

Segundo Agamben, é essa natureza escatológica do gesto que o bom fotógrafo sabe colher, sem, porém, diminuir em nada a historicidade e singularidade do evento fotografado. Ele cita algumas fotografias de caráter documental e afirma: "todas essas fotos contêm um inconfundível indício histórico, uma data inesquecível e, contudo, graças ao poder especial do gesto, tal indício remete agora a outro tempo, mais atual e mais urgente do que qualquer outro tempo cronológico". (AGAMBEN, 2007, p.28).

Além da situação fotografada, outro aspecto da fotografia que encanta o filósofo e ao mesmo tempo o intriga é a exigência do sujeito fotografado de não ser esquecido. Assim essa exigência que nada tem de factual se transforma num imperativo da defesa do sujeito histórico na representação:

Mesmo que a pessoa fotografada fosse hoje completamente esquecida, mesmo que seu nome fosse apagado para sempre da memória dos homens, mesmo assim, apesar disso - ou melhor, precisamente por isso - aquela pessoa, aquele rosto exigem o seu nome, exigem que não sejam esquecidos. (AGAMBEN, 2007, p.29). 
Uma exigência que anima todas as fotografias e capta o real que está sempre no ato de se perder para torná-lo novamente possível. Dessa forma, a fotografia, conclui Agamben (2007, p.30), “exige que nos recordemos; as fotos são testemunhos de todos esses nomes perdidos, semelhantes ao livro da vida que o novo anjo apocalíptico o anjo da fotografia - tem entre as mãos no final dos dias, ou seja, todos os dias".

A leitura de Agamben foi ao encontro de uma reviravolta epistemológica que venho ensaiando em outros trabalhos ${ }^{6}$, nos quais venho pensando o engajamento como autoria e a autoria como a presença o sujeito-autor na obra. Na linha de Agamben, o autor é aquele cujo gesto de jogar com e nos dispositivos coloca em evidência a ausência de uma presença. Contraditoriamente, o sujeito que se apresenta numa fotografia não está mais presente, foi jogado na fotografia e a sua existência implica na sua própria desaparição.

O autor da fotografia, o fotógrafo, opera um dispositivo que captura uma presença que definirá no futuro uma dupla ausência - do objeto fotografado e do próprio fotógrafo que não existe mais a não ser no fora de quadro, no fantasma de alguém que some na espuma do tempo.

O gesto de jogar o sujeito na fotografia - de jogar na imagem que expressa uma dada condição histórica - coloca o sujeito-fotógrafo em relação aos dispositivos da linguagem política. O jogo que se desenrola na arena política é apropriado pela expressão fotográfica e o gesto do fotógrafo instaura uma presença ausente - os que lá estavam não mais estarão, mas permanecerão com seu rosto, com sua identidade de sujeitos históricos, nas imagens que circularão e serão reproduzidas, apropriadas e analisadas no vir-a-ser da história.

Por outro lado, cumpre uma função na cultura política do engajamento, pois confirma que o que foi não será esquecido, e aqui o

\footnotetext{
${ }^{6}$ Refiro-me aqui a dois trabalhos publicados recentemente em dois periódicos: O Olhar engajado: fotografia contemporânea e as dimensões políticas da cultura visual. Artcultura, Uberlândia, v.10, n.16, p.31-48, jan./jun. 2008 e Milton Guran, a fotografia em três tempos. Studium, Unicamp, n.28, 2008. Disponível em: http://www.studium.iar.unicamp.br/28/1/index.html.
} 
engajamento em uma causa define o 'autor como gesto' e garante a autoria como ação política. Neste sentido, o fotógrafo atua como mediador cultural ao traduzir em imagens técnicas sua experiência subjetiva frente ao mundo social. A noção de mediação cultural tal como apresentada por Willians Raymond (1979) e apropriada por diferentes pensadores latino-americanos tais como Martin-Barbero (1997) e Nestor Garcia Canclini (1989), permite romper com a ultrapassada teoria do reflexo e desvendar uma intricada rede de influências sociais que consubstanciam a produção cultural na sociedade capitalista. A ideia defendida por Raymond (1979) propõe associar mediação ao próprio ato de conhecer e elaborar expressões, no âmbito do ativo processo de produção de representações sociais. Portanto, segundo as formas como capitaliza essa experiência adquirida, o fotógrafo assume uma postura em face da realidade social que fotografa e, assim, consegue seu reconhecimento profissional.

Aliada à noção de prática fotográfica está uma outra ideia: o engajamento social ou político a um projeto, no qual o fotógrafo se associa para orientar seu arco de ação. Ao longo de uma trajetória, os projetos podem se modificar, embora não cessem de existir como condição própria da experiência fotográfica. Tais projetos não são absolutamente individuais, devem ser compartilhados por uma comunidade de sentido que fornece apoio para a ação e projeção individuais de cada fotógrafo. Assim, esses projetos possuem características variadas, podendo ser um vínculo profissional a uma agência de notícias, a um órgão da imprensa, a um movimento social, a uma vanguarda artística, participação num projeto de pesquisa etc.

Portanto, encerro essa parte conceitual evidenciando a ideia da fotografia como gesto e do engajamento como autoria, duas importantes referências para trabalhar com as fotografias de cobertura política, dentre elas as de Milton Guran, produzidas em 1979. 


\section{A fotografia como gesto e o engajamento como autoria}

Em 1979, com trinta anos de idade, o então fotojornalista Milton Guran partiu munido de duas câmeras fotográficas - uma Nikon FM e uma Leica e vários filmes Tri-X rebobinados - para uma cobertura jornalística autônoma do XXXI Congresso da UNE. Essa empreitada resultou, meses depois, na publicação de um livro composto por 56 fotografias que, pelo gesto de registrar fotograficamente o acontecimento, capturaram os sujeitos históricos e os projetaram na história.

O envolvimento na cobertura jornalística do evento é explicado por Guran?:

É... Nós vivíamos uma campanha pela Anistia, a UNE continuava proscrita, estavam começando os movimentos de greves do $\mathrm{ABC}$. Então, assistíamos a uma retomada da sociedade civil como protagonista de primeira ordem da cena política brasileira. Eu era repórter no Congresso Nacional, e pude avaliar a importância que tinha esse congresso da UNE. Sobre o congresso da UNE, a história foi a seguinte, que é aliás, a história desse livro. Eu era repórter no Congresso Nacional, como eu estou dizendo, e sentia a importância desse congresso na cena política brasileira, o engajamento dos partidos, principalmente do MDB na época. Sobretudo dos deputados da esquerda, da esquerda do MDB e... da importância que esse evento teria na tomada de temperatura do regime: por um lado as esquerdas iam tomar uma temperatura do regime, quer dizer, até onde o regime militar estava disposto a engolir sapo; e o regime militar tomava a temperatura da esquerda, até onde a esquerda vai se mostrar. E quem organizou isso, quer dizer, quem negociou a realização desse encontro foi o Antônio Carlos Magalhães, que era prefeito de Salvador, e ele emprestou para UNE, quer dizer, alugou por trinta dinheiros, não sei, o centro

\footnotetext{
${ }^{7}$ Entrevista realizada em 3 de setembro de 2009, no Rio de Janeiro. Gravada, com duração de 60 minutos, e depositada no Laboratório de História Oral e Imagem (LABHOI-UFF), Transcrição Luciano Gomes, www.historia.uff.br/labhoi .
} 
de convenções dele, que foi uma jogada muito boa, porque o centro de convenções era em um lugar afastado de Salvador. Era um super empreendimento, enorme e tudo e não havia sido inaugurado ainda e foi inaugurado com esse, com esse congresso que tomou o nome de... tomou o nome de... Encontro da UNE? Encontro é... o Antônio Carlos não permitiu que fosse chamado de trigésimo primeiro congresso da UNE, por que a UNE era ilegal! Então seria um encontro e aí eu fui e fotografei. [...] Tentei vender essas fotos no mercado, eu era repórter, freelancer, eu tinha sido demitido do Jornal de Brasília em função da minha atividade sindical e trabalhava numa revista de cooperativas e atuava com 'frila'. Mas, não consegui vender foto para nenhum jornal, nenhuma revista, ninguém quis foto do congresso da UNE. O congresso abriu com os estudantes decidindo que aquele encontro se chamaria trigésimo primeiro congresso da UNE quer dizer, retomando toda uma tradição da UNE e desafiando o governo. Então o congresso adquiriu um peso político real, quer dizer ele já tinha peso, mas ele adquiriu uma identidade política real como um congresso de reconstrução da entidade máxima dos estudantes brasileiros que é uma referência na... vida política da organização das forças populares desse país. A UNE é uma força política importante, a UNE teve um papel decisivo em vários momentos da história, inclusive na luta pelo petróleo, assim por diante, podemos contar histórias belíssimas da UNE.

A presença do fotógrafo como testemunha do acontecimento e a produção das imagens como registro de um movimento social não garantem a sua existência histórica. A existência do acontecimento, como relembra Guran, foi negada pela grande imprensa, pois nenhum jornal quis publicar as suas imagens. Em outro momento do seu depoimento, quando comenta uma das fotografias publicadas no livro, a presença desses outros agentes da mídia foi notada:

E é interessante que a foto seguinte, aparece um sujeito careca com a bandeira da UNE atrás e três microfones, ele falando com três microfones: à direita uma repórter da Globo, com o microfone da Globo; abaixado um sujeito com o som botando lá; abaixado na outra ponta o Silvio Tendler, segurando o microfone também aqui ó, é esse aqui. Aí, a legenda vai enriquecer a leitura dessa cena, 
'José Serra, gestor 63 - 64, último presidente vivo e em liberdade, invocando as tradições da UNE, declara aberto o trigésimo primeiro congresso’. Por isso a Globo estava lá...

A TV Globo garante o registro da figura pública, mas o registro televisivo, ao contrário da imagem impressa, é fugaz para guardar o registro como memória. Além disso, como menciona Guran em outra parte da entrevista, a TV Globo da Bahia era aliada ao governo do Antonio Carlos Magalhães, o mesmo que havia cedido o Centro de Convenções aos estudantes e queria ver a sua ação política e o espaço que estava inaugurando devidamente projetado na mídia da época.

Já a presença do cineasta Silvio Tendler revela outro aspecto dos registros visuais dessa época. Vale lembrar que uma geração de cineastas engajados nos movimentos sociais e na luta política produziram uma filmografia importante tanto documental como ficcional. ${ }^{8}$

O engajamento também era a marca da produção das imagens fotográficas, sendo que o próprio Guran, na época, estava envolvido nas lutas sindicais dos jornalistas. Por sua participação ativa na União dos Fotógrafos de Brasília, havia sido ele próprio um militante da UNE, como recorda ao ser indagado:

Eu tinha trinta anos, mas tinha militado aos 20 anos, quando a UNE existia, eu fiz parte da UNE, a UNE entrou para a ilegalidade no golpe de 64 e nós continuamos atuando, inclusive no último congresso da UNE que caiu todo mundo em Ibiúna eu ia, mas tinha um colega meu que tinha muita vontade de ir, ele disse: pô, deixa eu ir cara, deixa eu ir, então vai cara, foi, caiu né [...]. No último Congresso de Ibiúna eu era da é... eu era do diretório da comunicação da ECO.

Assim, as estratégias e táticas da ação autoral pelo engajamento orientam que todo o circuito da produção do texto visual seja apoiado

\footnotetext{
${ }^{8}$ Sobre esse tema ver: SILVA, Maria Carolina Granato da. O Cinema na greve e a greve no cinema: memórias dos metalúrgicos do ABC (1979-1981). 2008. Tese (Doutorado em História) - Universidade Federal Fluminense, 2008.
} 
pela noção de necessidade. Há uma necessidade de que o registro seja feito, há uma premência de que o acontecimento não se perca nos silenciamentos impostos pelo regime de exceção. Assim, o trabalho autoral de Guran só se realizaria com a veiculação das imagens, com a sua recepção por outros sujeitos, por outros estudantes que, pela experiência visual, agenciariam a ação social. Como isso foi feito? Pelas "exposições guerrilheiras", pela publicação do livro e pelas várias estratégias de divulgação, como enfatizou o fotógrafo na sua rememoração:

$\mathrm{Na}$ época eu era ligado ao Diretório Acadêmico da Faculdade de Arquitetura da UnB, cuja presidente era a Silvana Louzada, fotógrafa, nossa amiga, dileta e querida. E a Silvana disse: vamos fazer uma exposição no Diretório. E eu perguntei : como é que a gente vai fazer? O capitão de mar-e-guerra, que era o reitor da UnB, vai liquidar com a gente. Ela disse não, a gente faz durante a noite. Eu digo: está bem então será uma exposição guerrilheira. Nós entramos durante a noite, os estudantes de arquitetura tinham o hábito de passar a noite no laboratório de arquitetura e urbanismo fazendo projeto, tocando violão, namorando, enfim ficava por ali a noite toda. Então a segurança da UNB estava habituada com aquilo ali. Então a gente foi durante a noite. Eu ampliei as fotos, nós colocamos numa cartolina. Na manhã seguinte, os alunos chegaram para primeiro tempo de aula, se abriram as portas do laboratório de arquitetura, nós fomos para segundo andar e descemos um bandeirão da UNE e a estudantada toda entrou. Às 10 horas da manhã , quando finalmente a reitoria se organizou, tomou pé da coisa, já tinham passado 3 mil pessoas. O Jornal de Brasília já tinha sido avisado, Correio Braziliense estava indo para lá, a estudantada toda se reuniu ali, e a segurança da universidade fechou a exposição e confiscou tudo. Aí, o Correio Brasiliense que não pode fazer a matéria me perguntou: e agora Guran ? E foi aí que eu não sei exatamente como a minha boca se abriu e eu disse assim: e agora só me resta fazer um livro... fazer um livro por que não é possível que um livro seja proibido, que não se possa... então os estudantes se reúnem, fazem um congresso dessa ordem e não é possível que nesse país só tenha capitão de mar-eguerra para fechar, e confiscar livro, então nós vamos fazer o livro. Aí o Correio Brasiliense deu a notícia no dia seguinte, que eu ia fazer um livro da UNE, aí eu fiquei na obrigação de fazer o livro. 
O livro foi publicado pela Livraria Galileu Editora, um empreendimento editorial de esquerda que se comprometeu a ampliar a tiragem para cinco mil exemplares, com somente uma ressalva: a de não colocar UNE no título, para evitar perseguições na hora de emitir a nota fiscal ou qualquer outro registro do material, já que a UNE não estava legalizada naquele momento. Para garantir a presença do registro do evento uma estratégia foi utilizada, a de colocar na capa do livro uma foto com os dizeres: "A UNE somos nós".

A tática de publicação de um livro de fotografias foi eficiente para dar visibilidade ao acontecimento e, ao mesmo tempo, para garantir que ele fosse conhecido em outras partes. Para garantir isso uma rede de distribuição foi criada e as exposições guerrilheiras entraram em ação, como discorre Guran:

Então, nós resolvemos fazer esse livrinho. Uma livraria que ficava no ponto central de Brasília resolveu fazer um lançamento, então eu fiz uma exposição pequenininha das fotos para botar na livraria e fiz uma segunda "exposição guerrilheira", e essa que ganhou realmente a versão guerrilheira, por que ela era colada no papelão e embrulhada no plástico. Assim, naquele tempo não se plastificava, a gente passou um plástico e prendeu atrás. Isso foi numa caixinha e essa versão foi entregue a UNE para fazer circular clandestinamente - já que a UNE era clandestina entre aspas - pelo Brasil inteiro. Ela foi apresentada pela primeira vez, se não em falha a memória, no Rio Grande do Norte. E foto da capa foi feita uma camiseta que circulou pelo Brasil, eu tenho uma versão dessa camiseta [...]. Bom, esse material pereceu no incêndio da Agil e o que nós temos hoje é esse livrinho. Eu com 5.000 exemplares e o governo contra, distribuição difícil, ele vendeu muito, mas é uma tiragem muito alta, ainda hoje, para um livro de fotografia, uma revistinha como essa, então você imagina que esse livro acabou sendo distribuído e vendido por todos os sindicatos do país, todos os sindicatos progressistas, e pela UNE. Eu dei pra UNE acho que 500 exemplares pra eles venderem e fazerem finanças, ou mil, e para os sindicatos também. 
Paralelamente, a tática guerrilheira de espalhar pelo Brasil imagens do encontro indicava, naquela época, um certo tipo de compromisso. $\mathrm{O}$ compromisso com necessidade de ocupar um papel testemunhal e, ao mesmo tempo, o de incorporar a subjetividade na produção do testemunho ficam evidentes na estratégia adotada pela cobertura, na forma como o próprio fotógrafo concebe o ato fotográfico e o diferencia das demais maneiras de registrar:

E assim, esse livrinho, que é a primeira reportagem fotográfica inteira publicada de forma independente - e eu não tenho notícia de outra - é uma cobertura de evento, isso não é um ensaio! Isso é uma cobertura de evento político! Um evento político [...]. E o que é determinante aqui são os fatos que aconteceram, isso é uma cobertura factual, entendeu? Eu não fui à Bahia fotografar o que me desse na veneta. Eu fui à Bahia fotografar um acontecimento. [...] Uma crônica seria um comentário sobre esse acontecimento, a crônica é sempre um comentário, por isso ela é crônica, isso não é um comentário, isso é uma descrição densa do acontecimento, tem termos fotográficos, e o ensaio não é sobre o acontecimento, o ensaio inclusive descaracteriza o acontecimento, quando tem um acontecimento muito grande, você pode entrar no acontecimento e extrair imagens daquele acontecimento que não tem o objetivo de descrever o conjunto do acontecimento, tem o objetivo de apresentar uma versão pessoal do acontecimento a partir dos seus pressupostos internos $[\ldots]$. Dentro desse conjunto existem imagens que funcionam como um poema visual, essa da capa é uma delas, uma das poucas, aliás, que tem aí. [...] Uma coisa é o envolvimento e outra coisa é o compromisso, então é o seguinte: o meu compromisso aqui era de produzir um documento que desse conta, para os meu contemporâneos e para a posteridade, do que foi o congresso de reconstrução da União Nacional dos Estudantes [...]. Esse é o meu compromisso. A minha alma de poeta faz com que, vislumbrando a poesia em algum aspecto, eu procure captá-la em fotografia, isso aí é outra coisa, é um diletantismo meu que acontece ao mesmo tempo em que eu estou envolvido nessa problemática aí, entende? 
Assim a construção do compromisso na produção da reportagem se define pela total imersão na cena histórica, na capacidade do sujeitofotógrafo se identificar com a causa a ser fotografada:

Então, eu tive aqui nesse trabalho, a preocupação de descrever um acontecimento, então o livrinho apresenta as coisas em ordem cronológica. E eu cheguei lá antes do congresso começar. O congresso começava no dia 29 de maio de 79. Eu cheguei no dia 28 de maio, senti o clima da cidade, no dia 29 quando amanheceu o dia eu estava lá no centro de convenções. Então eu passei as 24 horas inteiras até o dia 30 de maio e o congresso terminou no dia 31 de maio as 4:30 da madrugada. E eu fiquei lá, sem sair, com a mesma roupa, dormindo encima dos bancos, como, aliás, todo mundo ficou, inclusive por que o negócio era longe à beça, a barra era pesada, e ocorreram vários acontecimentos desagradáveis, agressões, atentados, intimidações então ninguém saiu de lá, e eu fiquei lá também. [...] Eu era um garotão, misturado com todo mundo, estava lá entre os simpatizantes, e não estava sozinho, Silvio Tendler estava lá também. Então, aqui tem duas coisas interessantes que eu acho nesse livro aqui: uma é que ele é realmente uma reportagem, é tecnicamente uma reportagem de cobertura de evento que seguiu uma metodologia desenvolvida por mim quase que instintivamente. Quer dizer, eu fotografei tudo o que eu achava importante, eu representei na foto todo o tipo de gente que apareceu ali e dei destaque a tudo aquilo que eu achava que era politicamente relevante dentro da perspectiva de que isto era uma manifestação da sociedade civil. Então quer dizer, eu estava inserido dentro de um contexto político maior e dentro de uma cidade específica e um momento político específico. Eu, como a maioria das pessoas ali, como todo mundo, nós tínhamos a perfeita consciência da manipulação que estava sendo feita pelo ACM, pelo regime militar, e tudo mais. Quer dizer, não tinha nenhuma inocência ali. Foi tudo feito com luz natural, sem flash em nenhum momento, todas as fotos apresentadas aqui estão com a integridade do negativo, para que isso ficasse bem claro eu botei a borda preta do negativo, para dizer que não houve corte, dentro da tradição documental francesa da primeira metade do século XX. Isso significa que, existe aqui o compromisso do fotógrafo de mostrar que ele não cortou, com exceção de uma única foto que era a ponta de um filme rebobinado, e aqui também 
isso serve de indício para mostrar as limitações econômicas da cobertura, pois era uma ponta de filme rebobinado, que não terminou por que aqui tinha a fita gomada que prendia o filme na bobina. [...] Mas era uma foto importante de uma credencial falsificada pela polícia, então, para agentes infiltrados e eu fiz questão de mostrar essa foto, então ela não tem um dos lados da borda preta porque o negativo acabava ali, porque era um filme rebobinado, se fosse um filme original de fábrica isso não aconteceria. Então, essa reportagem tem, em termos de técnica de reportagem e em termos de técnica fotográfica, um valor exemplar na minha opinião, como professor de fotografia de fotojornalismo, trinta anos depois. Isso quer dizer, essa exposição que está aqui, essa reportagem, esse livrinho, ele materializou toda uma experiência que eu já tinha como jornalista e como repórter fotográfico.

Na cobertura foram produzidas mais de quinhentas imagens, dentre as quais cinquenta e seis ganharam visibilidade pelas táticas da divulgação, que dadas às condições históricas da época, foi bastante ampla como já comentado. Foi justamente essa tática de tornar público o trabalho que garantiu a sua posteridade, tendo em vista que os negativos das demais fotografias produzidas na cobertura foram perdidos no incêndio criminoso que a Agência Ágil ${ }^{9}$ sofreu em meados dos anos 80 .

Dentre esse conjunto de imagens que, como peças de um mosaico, poderia ser reordenado ao sabor do compromisso político com a causa, concentro-me naquela que foi eleita a fotografia da capa pelo próprio Guran (Figura 1). A opção foi justificada pela eficiência em sintetizar o momento de fim do encontro da UNE e por, ao ser colocada na capa, incluir a sigla UNE no título, garantindo que o referente da imagem fosse o próprio acontecimento. No entanto, sua escolha revela que a fotografia, como um gesto de engajamento, de compromisso com uma causa, pode vislumbrar um poema. Este, à maneira de Agamben, está no gesto no qual o autor, as pessoas fotografadas e todos que as veem se põem em jogo na

\footnotetext{
${ }^{9}$ A Agil Fotojornalismo foi uma agência de fotógrafos independentes, sediada em Brasília, criada no início de 1980 pelos fotógrafos Milton Guran, Duda Bentes, Beth Cruz, Kim-ir-sen, Júlio Bernardes e André Dusek.
} 
imagem e, ao mesmo tempo, infinitamente fogem disso. Somos como nos mostramos nas imagens, mas não somos mais aquilo que vemos na imagem. Essa é uma aporia temporal que qualquer fotografia deve enfrentar.

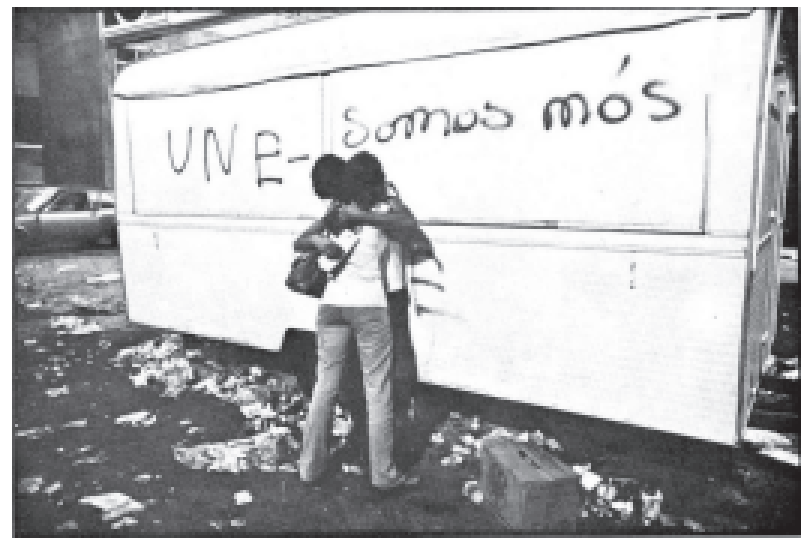

Figura 1 - 4 h30 (da madrugada) de 31 de maio de 1979 Fotografia: Milton Guran Fonte: Guran (1979)

Ao longo da entrevista, Guran foi descrevendo as várias fotografias e evidenciando a construção daquilo que ele denominou discurso visual. Ao chegar à última imagem e que é também a fotografia escolhida para a capa, foi identificada pelo fotógrafo como um poema visual. Eu pedi que ele a comentasse. $\mathrm{O}$ pedido que foi prontamente atendido:

Vou comentar, ela tem como legenda: " $04 \mathrm{~h} 30 \mathrm{~min}$ da madrugada de 31 de maio de 79". E ela é um desses trailers que vende sanduíche, branco, com uma pichação em cima: "UNE - somos nós" e um casal se abraça. Tem um rapaz e uma moça que tão se abraçando, é um casal, é um abraço de amor, mas não é um beijo, não é um abraço romântico, é um abraço mesmo, é um abraço forte, um abraço de uma moça e um rapaz, e um abraço, sobretudo de seres humanos que tão juntos nisso aí, não é um abraço sensual, um abraço romântico, é um abraço que foi além de tudo, esse casal de namorados, foi lá, passou lá é... 50 horas como eu, entrou no dia 29, foi até o dia 30 de manhã, depois foi do 30 ao dia 31 de manhã, passou o dia 31 inteiro e foi terminar as quatro e meia da manhã do dia 31 , você tá me entendendo? Do dia 31 , quer dizer, então ele 
passou, sei lá, 60 horas, mais de 60 horas envolvido com aquilo e o resultado é isso, papel pelo chão, à noite, iluminado por um poste de iluminação pública eles se encontraram e se abraçaram, aí nesse container, com essa palavra de ordem. [...] Eu estava indo embora, com o equipamento na mão, fotógrafo, com a máquina pendurada, fotografando tudo, caminhando, a gente era 10.000 para sair dali, o congresso tinha acabado, a gente ia andando, não tinha condução, não tinha nada, a gente tinha que sair em grupo, era clandestino, ninguém sabia, aquela coisa, clandestino entre aspas, né? Então, lá fomos nós e eu vi essa cena e naturalmente, percebi logo o alcance simbólico disso aí, e cravei. Isso ai é um 60/ 5.6, 30/5.6, com a lente normal, 30 de velocidade e 5.6 de diafragma, com a máquina na mão não se vê rosto, e essa foto é uma coisa interessante. Anos depois, em uma manifestação por eleições diretas na frente do Congresso Nacional e eu fui procurado por uma moça que veio falar comigo eufórica e disse assim: Você é o Milton Guran? Eu disse sou. E você quem é? Eu sou a garota da foto! Eu sou a garota da UNE! Ela estava feliz por que ela era a garota da UNE! E é interessante porque você vê que é uma garota pelo desenho do corpo, por que ela está vestida de rapaz, de calça comprida... Não... tinha muita menina vestida de menina. [...] É... camiseta, saia florida, vestidão largo, bata, mas ela está de camiseta curta, de calça comprida. [...] Então, essa foto que fecha o livro, na verdade, é a síntese dessa assembleia de estudantes, que... é... é... dessa assembléia de estudantes que teve a particularidade de mostrar o rosto da juventude brasileira, que foi a juventude que na rua brigou por diretas e depois incentivou o secundarista a pintar a cara no episódio do Collor. Sem o trigésimo primeiro congresso da UNE, dificilmente aconteceriam os caras pintadas!

Aqui, não vou me deter na análise da mensagem fotográfica, pois seria desnecessário, face à eloquência da fonte oral. Prefiro recuperar uma reflexão de Agamben (2007, p.29), na qual ele afirma que "a imagem fotográfica é sempre mais que uma imagem: é o lugar de um descarte, de um fragmento sublime entre o sensível e o inteligível, entre a cópia e a realidade, entre a lembrança e a esperança".

$\mathrm{O}$ ato fotográfico implica num corte na continuidade de um mundo visível em estado de movimento e isso fica explicito no relato acima. No entanto, esta atitude de corte, na situação acima descrita, vai além, pois o 
fotógrafo age como um guerrilheiro que marcha na batalha final atirando para todos os lados. Ombro a ombro com os camaradas que compartilha o compromisso de lutar até o fim, gasta toda a sua munição, até o último rolo de filme. Coisa alguma ficará sem memória, ninguém deixará de existir na história.

O interessante é que a imagem não revela rostos, mas identifica sujeitos; não inclui a paisagem, mas situa o espaço. Não aponta o tempo, mas os papéis pelo chão, o trailer fechado e o abraço cansado definem a experiência de um fim. Não apresenta o evento, mas indica a sua presença pelas marcas textuais e pela palavra de ordem UNE somos nós, ou ainda pelas marcas visuais dos jovens se abraçando. A composição precisa cria um poema visual que define a fotografia como gesto e o engajamento como autoria.

\section{Considerações finais: o Congresso da UNE nas lentes de Milton Guran}

Reconstruir as trajetórias dos fotógrafos através de entrevistas de história de vida tem sido um trabalho especial. Os distintos percursos profissionais revelam projetos que se orientam segundo escolhas num campo amplo de possibilidades. Algumas escolhas evidenciam a adesão a um perfil profissional, ao cumprimento de pautas editoriais, ou ainda, às aspirações artísticas e à distinção de um métier, reconhecido pelos pares do ofício como excepcional. Entretanto, aquelas que realmente se decalcam a percepção do sujeito como agente transcendem a vontade individual e são compartilhadas como uma necessidade coletiva. Nesse sentido, as práticas consubstanciadas por essas escolhas, expressam o engajamento a um projeto, cujo sentido, transcende a ação imediata transformando-a num meio de criação.

A fotografia como a expressão de um gesto, de uma ação de criação, tem a sua marca autoral garantida pelo engajamento a uma causa. 
O olhar engajado revela-se nos temas, nas formas, nas opções de linguagem, na expectativa de conseguir a foto mais representativa daquele momento vivido e compartilhado coletivamente. Milton Guran, ao longo dos dias do Congresso da UNE, de 1979 ,em Salvador, misturou-se aos estudantes e colocou as suas lentes a serviço de uma causa, o resultado foi a produção de fotografias que não só expressam visualmente momentos de impacto e envolvimento, como registram um acontecimento projetandoo como História para a posteridade. Essa forma de engajamento revela a potência da autoria de sua fotografia.

\section{Referências}

AGAMBEN, Giorgio. Profanações. Tradução e apresentação de Selvino José Assman. São Paulo: Boitempo, 2007. (Coleção Marxismo e Literatura).

BARTHES, Roland. A câmara clara. Rio de Janeiro: Nova Fronteira, 1984.

CANCLINI, Néstor Garcia. Culturas híbridas: estratégias para entrar y salir de la modernidad. México, DF: Grijalbo, Consejo Nacional para la Cultura y las Artes, 1989.

FOUCAULT, M. O que é um autor? Lisboa: Vega, 1992.

GURAN, Milton. O Encontro na Bahia: XXXI Congresso da UNE. Brasília: Galilei, 1979.

KRACAUER, Siegfried. Photography. In: TRACHETENBERG, Alan (Ed.). Classic essays on photography. New Haven: Leete's Island Books, 1980. p.245-268. 
MARTIN-BARBERO, Jesús. Dos meios às mediações:

comunicação, cultura e hegemonia. Rio de Janeiro: Ed. UFRJ, 1997.

MATOS, Olgária. Profanações. In: AGAMBEN, Giorgio.

Profanações. Tradução e apresentação de Selvino José Assman.

São Paulo: Boitempo, 2007. (Coleção Marxismo e Literatura).

MAUAD, Ana Maria. O olhar engajado: fotografia contemporânea e as dimensões políticas da cultura visual. ArtCultura, Uberlândia, v.10, n.16, jan./jun. 2008, p.31-48.

RAYMOND, Willians. Marxismo e literatura. Rio de Janeiro: Zahar, 1979. 